\title{
Technology, Capital Spending, and Capacity Utilization
}

\author{
Cynthia Bansak \\ San Diego State University \\ Norman Morin \\ Federal Reserve Board \\ Martha Starr \\ American University
}

May 2004

\begin{abstract}
$\underline{\text { Abstract }}$
This paper examines the relationships between technology, capital spending, and capacity utilization. Recent technological changes have increased the flexibility of relationships between inputs and outputs in manufacturing, which may have eroded the predictive value of the utilization rate. This paper considers how technology might be expected to affect utilization. We show that recent changes could either lower average utilization by making it cheaper to hold excess capacity, or raise utilization by making further changes in capacity less costly and time-consuming. We then examine the effects of technology on utilization, using data on 111 manufacturing industries from 1974 to 2000. The results suggest that, for the average industry, the technological change of that period had a modest but appreciable effect, shaving between 0.2 percentage point and 2.3 percentage points off the utilization rate.
\end{abstract}

JEL codes: D24, E22, E31.

We are grateful to James Adams, Ana Aizcorbe, Ed Balsdon, Ernst Bernt, Joe Beaulieu, Darrel Cohen, Carol Corrado, Kusum Mundra, seminar participants at American University, and participants at the session on "New Developments in Productivity Measurement and Technology" at the 2002 ASSA meetings for valuable comments on earlier versions of this paper. All views expressed in this paper are those of the authors and do not necessarily reflect those of the Federal Reserve Board of Governors or its staff. 


\section{$\underline{\text { Introduction }}$}

Capacity utilization is a variable of longstanding macroeconomic interest. Many studies have found it to be a valuable indicator of inflationary pressure. For example, Cecchetti (1995) finds that capacity utilization works as well as or better than other variables in predicting inflation over the next year or two. Similarly, in models of the level of resource utilization above which inflation accelerates, the utilization rate does as well as, and sometimes better than, the unemployment rate in predicting this level. ${ }^{1}$ This predictive value may reflect capacity utilization's ability to do "double-duty," picking up the extent of slack in both labor and product markets (Corrado and Mattey 1997).

However, in recent years, the capacity utilization and unemployment rates have at times provided different signals about the degree of tightness in resource markets. Notably, in the late 1990s, the decline in the unemployment rate below 4 percent suggested a relatively tight labor market, but the capacity utilization rate remained unexpectedly flat (figure 1). Part of this divergence may be due to effects of technology on capacity utilization, as the 1990s saw both an investment boom that broadly increased manufacturing capacity and a shift in the composition of capacity toward high-tech machinery and equipment. In the 1940s and 1950s, manufacturing methods typically involved assembly-line production with large-scale, fixed units of machinery and equipment. Relationships between inputs and outputs were relatively fixed, and adjustments in capacity were both costly and slow. Modern manufacturing methods, however, build considerable flexibility into the management of capacity. Technologies like numerically-controlled machines, programmable controllers, and modular assembly make it easier to adjust the level and composition of output. At the same time, the use of automated design and modular tooling lowers the cost and time needed to expand capacity. While the use of advanced technologies is far from universal, it is increasingly widespread. For example, about three-quarters of plants in equipment-producing industries used at least one advanced technology in 1993; about 30 percent used five or

\footnotetext{
${ }^{1}$ See McElhattan (1978), Corrado and Mattey (1997), and Brayton, Roberts and Williams (1999).
} 
more. ${ }^{2}$ With the investment boom that took place in the second part of the $1990 \mathrm{~s}$, these shares are likely higher now.

Conceptually, how these advances in technology would affect capacity utilization is not clear a priori. On one hand, flexible manufacturing makes it easier to ramp production up and down. This may encourage firms to install a broader margin of excess capacity - that is, to operate at lower average utilization - in order to be able to handle upswings in demand. Such a strategy would be favored by declining prices of high-tech capital, which make excess capacity cheap. On the other hand, automated design and modular tooling make it faster and cheaper to for firms to expand capacity. This may permit them to reduce the amount of excess capacity they maintain, and to operate at higher utilization on average. With these two offsetting forces at work, determining how advances in technology affect capacity utilization is ultimately an empirical question.

This paper investigates the relationship between capacity utilization and high-tech investment. The next section discusses conceptual considerations in the relationship between technological change, capital spending, and capacity utilization. We show how technological change may lead either to lower average utilization by making it cheaper to hold excess capacity, or to higher utilization by making further changes in capacity less costly and time-consuming. The third section discusses the data and specification used for our study. The extent of investment in high-tech machinery and equipment has varied importantly across industries and over time. Thus, we use data on 111 manufacturing industries from 1974 to 2000 and panel data techniques to investigate effects of technology on utilization. We find significant negative effects of technological change on utilization, controlling for output growth, investment level, and other factors. Our estimates suggest that, ceteris paribus, for the average industry, the technological change of the past 25 years would shave between 0.2 percentage point and 2.3 percentage points off the utilization rate by the time the effects are fully realized. The final section of the paper discusses implications and concludes.

\footnotetext{
${ }^{2}$ U.S. Census Bureau (1994). 'Advanced technologies' included numerically-controlled machines, computer-aided design or engineering technologies, programmable controllers, local area networks, robotics, and other advanced methods.
} 


\section{$\underline{\text { Conceptual framework }}$}

Recent research on resource utilization emphasizes the levels of capital and labor used in production, relative to their total stocks, rather than the level of output relative to its potential (see, for example, Basu, Fernald and Shapiro 2001). This emphasis is clearly important for understanding factor productivities and how they may change over time. However, as Corrado and Mattey (1997) and Gordon (1998) have explained, the broader notion of capacity utilization remains an important alternative indicator of conditions in resource markets, gauging the extent to which firms could meet an increase in demand without additional capital investment.

Existing theoretical and empirical work has tended to view capacity utilization and capital investment decisions as independent, with utilization decisions made in the shortrun, and capital investment decisions made in the long-run. In practice, it is unclear that these decisions are so independent: In response to all but the most transitory demand or cost shocks, firms may change their utilization of existing capacity, change the level of capacity using existing technology, or change capacity and technology at the same time. Especially in an era when new vintages of capital equipment offer opportunities for significant efficiency gains, these interrelations between capacity, capital investment, and technological change may be particularly important.

To begin to think about relationships between technology and capacity utilization, it is helpful to sketch out a simple conceptual framework. The discussion that follows is largely intuitive; we hope to develop this framework in our future work. Suppose that firms have a certain amount of capacity in place initially. They receive information about demand at the outset of the current period; this information may also modify their expectations of future demand. Firms may then either: (a) change output without changing capacity, (b) change output and change capacity, using existing technology; or (c) change output and change capacity, using new technology. Which strategy is chosen 
depends on expected profitability. We can broadly sketch out the factors affecting the choice of strategy.

- Changing output without changing capacity enables firms to respond quickly to changes in demand, and does not involve costs of installing new capacity or reducing its excess. However, running at a high rate of utilization persistently may raise unit costs, and running at a low rate persistently is wasteful. When firms use this strategy to respond to demand shocks, utilization will fluctuate closely with demand.

- Changing output and changing capacity using existing technology involves fixed costs of adjusting capacity and a lag till capacity reaches its new level; adjusting capacity may also divert resources from productive use in the short-run. ${ }^{3}$

However, this strategy permits a higher level of output to be sustained without rising costs. Use of this strategy in response to a demand shock will set off a dynamic adjustment of utilization: for example, if a permanent increase in demand is accommodated by increasing capacity, the utilization rate may hold steady or rise initially, fall when new capacity comes online, then return to its previous average rate when adjustment is complete.

- Changing output and changing capacity using new technology resembles the previous strategy, but involves a change in technique. As above, this strategy involves fixed costs, a lag till new capacity comes on line, and lost output in the short-run; however, the levels of costs and length of lag may be different. Also as above, this strategy permits a higher level of output without rising costs.

However, the new technology may provide an opportunity to reduce unit costs, making profitability higher than it would be with the old technique once new capacity is online. Again, use of this strategy in response to a demand shock may set off a dynamic adjustment process. But here the utilization rate may not return

\footnotetext{
${ }^{3}$ For example, see Cooper, Haltiwanger, and Power (1999). In terms of downward adjustments, Ramey and Shapiro (2001) document important costs of disposing of redundant capital in the aerospace industry.
} 
to its previous average. Depending on capital costs and properties of the new technology, firms may want to hold more excess capacity than they did before if doing so is cheap; alternatively, they may want to hold less excess capacity on average if the new technology makes further changes in capacity less costly and time-consuming.

These considerations point to several factors that would lead one strategy to be favored over the others. First, the persistence of the demand shock obviously matters: if upfront costs of adjusting capacity are appreciable, a firm would handle temporary changes in demand by increasing utilization, and permanent changes by adjusting the capacity level. Second, the extent to which capacity changes are favored over changes in utilization depends on the costs involved. Notably, capacity changes are more likely to be undertaken when: the loss in output from diverting productive resources is small, the lag till new capacity comes online is short, and/or the costs of installing new capacity are cheap [or cost savings from reducing capacity are large]. Third, the decision to adjust capacity with existing methods, as opposed to with new technology, depends on how the costs and lags of implementing each strategy compare, and on differences in operating cost once new capacity comes online.

One can suggest several ways in which recent technological changes may have affected the relative returns to these strategies. First, automated design and modular tooling have reduced fixed costs of expanding capacity and have shortened lags till new capacity can be brought on line. This may generally raise the relative attractiveness of capacity adjustments over changes in utilization. Second, declining prices of capital goods also improve the profitability of capacity expansion over changes in utilization by making additions to capacity cheaper. Third, prices of capital goods embodying new technology have fallen disproportionately. This would particularly favor capacity changes with a 
shift in technique. And finally, new technologies provide opportunities to lower unit costs significantly, again favoring capacity changes with a shift in technique. ${ }^{4}$

The high level of investment in the 1990s, especially in high-tech machinery and equipment, is consistent with an increase in the relative attractiveness of expanding capacity and changing technology, in response to strong demand. Even so, the implications of this shift for capacity utilization are less clear. As mentioned, new technologies may make it easier to ramp production up and down. Combined with falling prices of high-tech equipment, this may encourage firms to install a broader margin of excess capacity -- operating at lower average utilization - to be able to handle upswings in demand. But because automated design and modular units make capacity expansion faster and cheaper, firms may prefer to operate at higher average utilization, expecting to be able to boost capacity should demand turn out to be strong. With these two offsetting forces at work, determining how advances in technology affect capacity utilization is ultimately an empirical question. Yet as the above analysis indicates, detecting effects of technology may not be straightforward, partly because capital spending, utilization, and technology are related in complex ways, and partly because effects of technology on utilization may be different in the short-run than they are in the long-run.

\section{Data and specification}

While many micro studies have examined how new technologies affect productivity, ${ }^{5}$ there has been little direct investigation of effects of flexible manufacturing on capacity utilization. This in part reflects data availability. Micro data on capacity and its utilization are collected in the Survey of Plant Capacity (SPC), which is conducted annually by the U.S. Census Bureau. ${ }^{6}$ However, the SPC collects only a few variables needed to estimate capacity utilization, and has no information on capital spending or technology. ${ }^{7}$ Capacity

\footnotetext{
${ }^{4}$ It can be noted that firms also cite greater volatility in demand as a reason for adopting flexible methods, with increased global competition and downstream adoption of just-in-time methods said to be responsible. See for example Abernathy et al (1999) and Dunlop and Weil (1996).

${ }^{5}$ See, for example, Berndt and Morrison (1995) and Ichniowski and Shaw (1995).

${ }^{6}$ See U.S. Census Bureau (2001) for a description of the survey.

${ }^{7}$ For years before 1995, data from the SPC can be linked to the more detailed information contained in the Annual Survey of Manufactures.
} 
data are available for the auto industry, and have been analyzed by Van Biesebroeck (2000). He finds that auto-assembly plants using lean manufacturing methods have lower fixed and variable costs of adding shifts, compared to plants using traditional methods. This is consistent with the idea that costs of adjusting output are lower under new technologies.

To explore relationships between capacity utilization and technology, we make use of variation across industries and over time in adoption of new technologies. Although we think of high-tech investment as having picked up appreciably in the 1990s, some technologies like microcomputers and programmable automation have been gaining in use since the 1970s. ${ }^{8}$ Certain industries began investing in high-tech machinery and equipment early on; others have been latecomers. In some industries, adoption of hightech methods has been appreciable, while in others there has been very little. Figure 2 provides some insight into cross-industry variation in high-tech capitalization. The data are for 111 three-digit manufacturing industries from 1974 to 2000. The figure shows two important measures of high-tech that we use in our econometric work: investment in computer, office and communication equipment as a share of total investment, and capital in computer, office and communication equipment as a share of total capital. ${ }^{9}$ These variables are taken from Federal Reserve data sources, as described in detail in the Appendix. Investment in computers is clearly an important component of automated design and flexible methods, and is likely well correlated with adoption of such practices. However, it does not capture the full range of high-tech machinery and equipment used in manufacturing. Notably, some high-tech items (e.g. pick and place robots) fall into the other categories of investment, like industrial machinery, that contain both high-tech capital and other types. Nonetheless, given the importance of computers in making use of such items, we suspect that variation in the computer series will capture variation in use of related items reasonably well.

\footnotetext{
${ }^{8}$ See U.S. Congress, Office of Technology Assessment (1984).

${ }^{9}$ The computer and office equipment category is comprised of mainframes, personal computers and integrated devices, storage devices, printers, computer displays (monitors), and office and accounting machinery. The communications category includes telephone, telegraph, fax, modems, fiber optics, mobile communications, radio, television, aeronautical, and broadcast equipment.
} 
As the top panel of the chart shows, the average industry had $4 \%$ to $6 \%$ of its investment in high-tech equipment in the mid-1970s. This share rose to almost $10 \%$ in the mid1980s, dropped back as that decade went on, then picked back up in the 1990s, reaching almost $12 \%$ by 2000 . However, there was an appreciable spread around the average: for example, during this period, the investment share at the $25^{\text {th }}$ percentile held steady at or below $5 \%$, while at the $75^{\text {th }}$ percentile it has been as high as $14 \%$. At the lower-end of the range are industries processing raw materials, largely 'old' manufacturing sectors (e.g. fabric mills, yarn and thread, logging, saw mills, miscellaneous primary metals, etc.). At the high-end of the range are industries that themselves produce high-tech goods (e.g. computers and office equipment, communications equipment, electrical industrial apparatus, guided missiles and space vehicles). As shown in the lower panel of the chart, results are qualitatively similar for the high-tech share of capital stock. ${ }^{10}$

We use this variation across industries and over time to investigate relationships between capacity utilization and technological change. The basic specification estimated in our work is as follows:

$$
\begin{gathered}
C U_{j t}=\alpha+\beta_{1} C U_{j t-1}+\beta_{2} \Delta I P_{j t-1}+\beta_{3} I / K_{j t-1}+\beta_{4} S T D E V_{j t-1}+ \\
\beta_{5} \Delta A G E_{j t-1}^{x . h t}+\beta_{6} \Delta A G E_{j t-1}^{h t}+\delta_{89} D 89_{t}+\delta_{95} D 95_{t}+ \\
Z_{j t-1} \phi+\varepsilon_{j t}
\end{gathered}
$$

where the subscript $\mathrm{j}$ refers to sector $\mathrm{j}=1$ to 111 and $\mathrm{t}$ refers to years $\mathrm{t}=1974$ to 2000 and the other variables are defined as follows:

$$
\begin{array}{ll}
\mathrm{CU}_{\mathrm{jt}} & =\text { capacity utilization } \\
\Delta I P_{j t} & =\text { change in industrial output } \\
I / K_{j t} & =\text { ratio of investment to capital }
\end{array}
$$

\footnotetext{
${ }^{10}$ Note that there is a fair amount of persistence over time in industries' investment and capital shares. For example, over our sample period, correlations in five-year averages of investment shares are 0.80-0.90 from one five-year period to another; e.g. there is a correlation of 0.93 in industries' average investment shares for 1976-80 and 1981-85. But the correlation declines for periods farther apart; e.g. the correlation in average investment shares for 1976-80 and 1996-2000 is 0.68 .
} 
$S T D E V_{j t} \quad=$ standard deviation of IP [10-year rolling window]

$\triangle A G E_{j t}{ }^{x . h t} \quad=$ change in average age of capital equipment, excluding high-tech

$\triangle A G E_{j t}{ }^{h t} \quad=$ change in average age of the high-tech capital equipment

$D 89_{t}=$ dummy variable equal to 1 for years 1989 and after; 0 otherwise

$D 95_{t}=$ dummy variable equal to 1 for years 1995 and after; 0 otherwise

$Z_{j t} \quad=$ some measure or set of measures of high-tech capital or investment

The data on capacity utilization are industry averages tabulated from the SPC. ${ }^{11}$ The lagged dependent variable is included to address the presence of autocorrelated errors. The variables $\triangle I P, I / K$, and $S T D E V$ are intended to capture effects on utilization of output growth, investment level, and output volatility respectively; they are included in lagged form to avoid problems with simultaneity. We include two measures of the change in average age of capital stock: one for capital excluding high-tech equipment and structures, and the other for high-tech equipment. ${ }^{12}$ These variables will reflect changes in utilization that may be associated with aging or with vintage effects. The dummy variables D89 and D95 are included because survey questions and methods were revised appreciably in 1989 and again in 1995, potentially affecting measured utilization. ${ }^{13}$ To measure variation in the prevalence of new technologies, we rely primarily on two variables: the share of high-tech equipment in total investment, and the share of high-tech equipment in the capital stock. For each of these variables, we run the above regression using the lagged variable, the lagged change in the variable, and both the lagged variable and its lagged change. Details of variable definitions and data sources are given in the appendix.

\footnotetext{
${ }^{11}$ In that survey, a panel sample of manufacturing establishments is asked a brief set of questions about actual production and production at capacity. The sample is re-drawn every five years. Although the survey questions have changed somewhat over time, in general they are intended to measure the notion of 'capacity' underlying Federal Reserve statistics on capacity utilization, namely the "maximum level of production [a plant] could reasonably be expected to attain under normal and realistic operating conditions," assuming normal downtime for maintenance and repair, a representative product mix, and sufficient availability of inputs to operate capital in place. The survey data are used as inputs into Fed statistics on capacity utilization for sectors for which physical product measures are not available.

${ }^{12}$ Structures are omitted since our interest is in productive capital, for which aging would be overstated by including buildings.

${ }^{13}$ See the appendix for details. In brief, the wording of the questions on capacity was changed in 1989 , and in 1995 the sample was expanded considerably.
} 
To accommodate the panel aspect of the data, we ran the model using both fixed- and random-effects. The fixed-effects version estimates separate intercepts that vary across industries; the random-effects version takes variation across industries to be normally distributed. ${ }^{14}$ Accounting for this variation is clearly important, as there are persistent differences in average utilization across industries. ${ }^{15}$ However, both the fixed- and random-effects models will be biased in the presence of a lagged dependent variable (Greene 2002). In the fixed effects model, Nickell (1981) has shown that, while this bias is appreciable when the time dimension of the panel is small, it declines as the time dimension increases, approaching zero as $\mathrm{T}$ approaches infinity (see also Anderson and Hsiao 1982). As we have 26 years of data, we expect the size of the bias to be relatively small, although some studies have suggested that it may still be appreciable in a panel of such length. ${ }^{16}$

To address the potential bias in the fixed effects model from lagged dependent variables, we utilized the GMM estimator proposed by Arellano and Bond (1991). The ArellanoBond estimator (hereafter A-B) uses as instruments the lagged levels of the lagged dependent variable and predetermined variables and first differences of strictly exogenous variables. In principle, this method results in a potentially very large instrument matrix; in practice, this can make the problem to impractical to estimate, in which case a maximum number of lags on the predetermined variables can be specified (in our case 4). As predetermined variables, we used the change in IP, the ratio of investment to capital, and the standard deviation of IP. ${ }^{17}$ In one-step estimation, the

\footnotetext{
${ }^{14}$ In general, the fixed-effects model is more appropriate when the units of observation constitute the population or a large part of it, rather than a random sample of units drawn from it (Hsiao 1986, Greene 2002). The units of observation in our data constitute virtually all 3-digit manufacturing sectors; only a few very small ones are not covered. The random-effects model relies on the assumption of no correlation between the regressors and the unobserved individual effects. Estimated effects will be inconsistent if this assumption is violated.

${ }^{15}$ In our data, average capacity utilization rates range from the 60 s to the mid- 80 s. Those on the lower end include transportation industries, while those on the upper end include many 'continuous processors' like pulp, paperboard, and petroleum manufacturing. See Mattey and Strongin (1995).

${ }^{16}$ Judson and Owen (1996) find that even in panel data with the time dimension as large as 30, the bias can be significant - on the order of $3 \%$ to $20 \%$ of the value of the true coefficient on the lagged dependent variable. However, the estimate of this coefficient would still have the right sign, and the bias in estimated coefficients on other variables would be relatively small.

${ }^{17} \mathrm{We}$ also tried other sets of predetermined variables, of which some did not appear to be valid based on the Sargan statistic testing the null that the overidentifying restrictions are valid, and/or there was evidence
} 
Sargan test of overidentifying restrictions rejected the null hypothesis that the overidentifying restrictions were valid. However, the Sargan test is known to overreject in the presence of heteroskedasticity, in which case there may be large efficiency gains from using the two-step estimator. The two-step Sargan test could not reject the null hypothesis that the over-identifying restrictions were valid. Following the recommendation of Arellano and Bond, we use the one-step results for inference, with standard errors estimated robustly. In both one- and two- two-step estimation, it was not possible to reject the null of no second-order autocorrelation in the differenced residuals, which would render the estimates inconsistent. ${ }^{18}$ Selected diagnostic statistics from the A-B models are presented in Appendix Table A2. As will be seen below, results from the A-B models turned out to be qualitatively very similar to those of the fixed- and randomeffects models. Table 1 shows results for the specifications using the high-tech share of total investment as the measure of new technology, while Table 2 uses the high-tech share of total capital as this measure.

Not surprisingly, in all versions of the regression, higher output growth is associated with increased capacity utilization, ceteris paribus. Also as one would expect, the investmentto-capital ratio has a significant negative effect: when investment has been high relative to the capital stock, ceteris paribus, the utilization rate tends to be lower. The measure of output volatility was included to gauge whether industries facing relatively high variability in demand might have relatively low utilization, for example, if firms in these industries keep wider margins of excess capacity on average. Results suggest that effects of volatility vary across specifications: greater output volatility tends to be associated with lower utilization, although there are a few cases in which the effect is not significant.

An increase in the average age of an industry's non-high-tech capital stock is associated with significantly lower utilization; this is consistent with either a 'vintage' effect and/or

of second-order autocorrelation in which case the estimates would be inconsistent (see Arellano and Bond 1991: 281-282).

${ }^{18}$ The null of no first-order autocorrelation is rejected, although this does not imply that the estimates are inconsistent (Arellano and Bond 1991: 281-282). 
a tendency to reduce utilization of older capital stock. In contrast, aging of the high-tech capital stock does not have significant effects in most specifications.

The dummy variables suggest that, other things being equal, average utilization rates were significantly lower from 1995 on. While this effect may partly capture differences in aggregate economic conditions, it probably primarily reflects the changes in survey methods mentioned earlier. This is suggested by comparisons of survey and physicalproduct data on utilization for the sectors that have both types of data. Notably, after 1995, survey-based rates often had flatter profiles than rates based on physical-product data. Considering that the later 1990s were also years of strong high-tech investment, failing to adjust for the change in survey method risks attributing too much of the flatness in measured utilization rates to technological change.

Turning to results on technological change, our results provide fairly robust evidence of a negative association between use of new technologies and capacity utilization. As shown in Table 1, having a relatively high share of investment in high-tech was associated with a lower utilization rate in the random-effects and A-B models, although not in the fixedeffects model (column 1). An increase in this share was also associated with lower utilization, whether or not we control for the level of the share (columns 2 and 3). As shown in Table 2, having a high share of capital stock in high-tech had a negative effect on the capacity utilization rate, ceteris paribus (column 1). An increase in the high-tech share of capital also had a negative effect, with or without controlling for the level of this share (columns 2 and 3 ).

Thus, by most measures our results show that increased use of technology is associated with a reduction in capacity utilization, controlling for output growth, investment, and other factors. Above we suggested that a change in technology may reduce utilization in the short-run, possibly in part because of diversion of resources from productive use. However, in the long-run, it could lead either to lower utilization by making it cheaper to hold excess capacity, or to higher utilization by making further changes in capacity less 
costly and time-consuming. Drawing the implications of our results in this respect requires understanding the dynamic properties of capacity utilization.

As can be seen in Tables 1 and 2, the coefficients on lagged capacity utilization are about 0.50 to $0.60 .{ }^{19}$ Thus, although a temporary increase in a technology measure would lead to lower utilization in the short-run, the effect would dwindle over time, and utilization would return to its original level in the long run. But important technological changes, such as automated design and flexible methods, are more likely to involve persistent increases in the technology measures. In the case of a permanent change in a technology measure (or set of measures) of $\Delta Z$, the long-run effect on capacity utilization would be given by:

$$
\Delta C U=\left[1 /\left(1-\beta_{1}\right)\right] \Delta Z \phi
$$

Our estimates imply that, with the term in brackets equal to about 2, utilization would decline in the long run, with the magnitude of the decline eventually about twice what it is in the short-run. This finding is consistent with the notion that new technologies make it cheaper to keep excess capacity on hand. ${ }^{20}$

The question arises, by how much has technological change held down utilization, other things being equal? To provide some estimates relevant to this question, we make use of the fact that, between 1974-79 and 1995-2000, for the average industry, the computer share of investment rose by 5.1 percentage points, while that of the capital stock rose about 4.4 percentage points. Both shares rose by an average of 0.3 percentage point per year. Table 3 uses our estimated coefficients to compute effects of these changes on utilization, assuming that these changes are permanent. The fixed- and random-effects estimates suggest that, for the average industry, the technological change that occurred in

\footnotetext{
${ }^{19}$ Using the Levin and Lin (1992) panel unit root tests, we strongly reject the unit-root null hypothesis in the panel of utilization rates.

${ }^{20}$ Conceivably, our results may substantially reflect the unusual declines in prices of capital goods in the 1990s. To test the importance of the 1990s experience in accounting for our results, we re-ran the models on data from the 1970s and 1980s only. The results were qualitatively similar; if anything, the negative influence of technology on utilization was somewhat larger in magnitude with the 1990s left out. This suggests that the negative influence is not a unique function of that decade.
} 
the last 26 years will shave between 0.2 percentage point and 1.4 percentage points off the utilization rate, by the time the effects are fully realized. Estimated effects for the A-B models are somewhat larger, including estimated declines of about 5 percentage-points in the models using the high-tech share of capital stock as the technology measure. Thus, while our estimates leave some uncertainty about the magnitude of the effect, they consistently suggest that technological change has led to declines in the utilization rate, of modest but appreciable magnitudes.

\section{Discussion and concluding remarks}

In sum, our results suggest significant negative effects of technological change on utilization, controlling for output growth, investment level, and other factors. This is consistent with the notion that flexible manufacturing encourages firms to install a broader margin of excess capacity, in order to be able to handle upswings in demand. As we have pointed out, this strategy has also been favored by declining prices of high-tech capital, which reduce the costs of holding excess capacity. Nonetheless, our current estimates suggest that effects of technology on utilization have been relatively modest, with most estimates placing the effect of technological change of the 1974-2000 period on the utilization rate of the average industry in the 0.2 to 2.3 percentage-point range.

Changes in the relationships between technology and utilization may in turn imply changes in the relationship between utilization and inflation. While this paper has not specifically examined the full set of interrelations between technology, utilization and inflation, ${ }^{21}$ our findings may shed some light on widely-noted changes in relationships between growth and inflation in the second half of the 1990s. Notably, our results suggest that technological change may have permitted firms to maintain wider margins of excess capacity. If this is indeed the case, the average firm may be better able to handle a period of strong demand, without moving onto a steeply-sloped part of the marginal cost curve. This may, in part, explain why manufacturing output grew strongly in the later 1990s

\footnotetext{
${ }^{21}$ See Shapiro (1989) and Gordon (1989) for discussion of the relationship between utilization and inflation.
} 
with little appreciable increase in inflation. Other factors, however, clearly were also involved, including the broad-based expansion of manufacturing capacity.

Finally, while our results suggest that technological advances have so far, on balance, favored installation of wider margins of extra capacity, we have pointed out that such changes as automated design and modular tooling make it faster and less costly to add to capacity. This may make it easier for firms to respond to a period of strong demand by boosting capacity in a timely way, again rather than increasing utilization into the region of rising marginal costs. Conceivably, this may imply that, at any given level of capacity utilization, the degree of inflationary pressure may be lower than it was in the past. Indeed, improved ability to use capacity expansion to respond to strong demand may have helped keep utilization and inflation moderate in the later 1990s, even while output grew strongly. Further evidence would be needed, however, to establish this link. 


\section{$\underline{\text { References }}$}

Abernathy, Frederick, John Dunlop, Janice Hammond, and David Weil (1999). A Stitch in Time: Lean Retailing and the Transformation of Manufacturing - Lessons from the Apparel and Textile Industries. (Oxford University Press).

Anderson, T.W. and Cheng Hsiao (1981). "Estimation of dynamic models with error components," Journal of the American Statistical Association, pp. 589-606.

Anderson, T.W., and Cheng Hsiao (1982). "Formulation and Estimation of Dynamic Models Using Panel Data," Journal of Econometrics, Vol. 18, pp. 47-82.

Arellano, Manuel and Stephen Bond (1991). "Some Tests of Specification for Panel Data: Monte Carlo Evidence and an Application to Employment Equations," Review of Economic Studies, Vol. 58, No. 2 (April), pp. 277-297.

Bacharach, M.B. (1965). "Estimating Nonnegative Matrices from Marginal Data," International Economic Review, Vol. 6, pp. 294-310.

Basu, Susanto, John G. Fernald, and Matthew D. Shapiro (2001). "Productivity Growth in the 1990s: Technology, Utilization, or Adjustment?" Carnegie-Rochester Conference Series on Public Policy, Vol. 55 (December), pp 117-65.

Berndt, Ernst and Catherine Morrison (1995). "High-tech Capital Formation and Economic Performance in U.S. Manufacturing Plants: An Exploratory Analysis," Journal of Econometrics, Vol. 65, pp. 9-43.

Brayton, Flint, John M. Roberts, and John C. Williams (1999). "What's Happened to the Phillips Curve?” Federal Reserve Discussion Paper 1999-49 (September).

Bureau of Labor Statistics (1983). "Trends in Multifactor Productivity, 1948-1981," BLS Bulletin No. 2178.

Cecchetti, Stephen G. (1995). "Inflation Indicators and Inflation Policy." In Ben Bernanke and Julio Rotemberg, eds., NBER Macroeconomics Annual. (Cambridge, MA: MIT Press), pp. 189-219.

Cooper, Russell, John Haltiwanger, and Laura Power (1999). "Machine Replacement and the Business Cycle: Lumps and Bumps," American Economic Review, Vol. 89, No. 4 (September), pp. 921-946.

Corrado, Carol, and Joe Mattey (1997). “Capacity Utilization,” Journal of Economic Perspectives, Vol. 11, No. 1 (Winter), pp. 151-167. 
Doyle, Maura P. "The 1989 Change in the Definition of Capacity: A Plant-Level Perspective." U.S. Census Bureau, Center for Economic Studies Working Paper CESWP-00-09.

Dunlop, John and David Weil (1996). "Diffusion and Performance of Modular Production in the U.S. Apparel Industry." Industrial Relations, Vol. 35, No. 3 (July).

Ferguson, Roger W. (2000). "The New Economy: Unanswered Questions for 2000." Remarks Before the Downtown Economists Club, New York, New York February 17, 2000

Gordon, Robert J. (1989). “Comments on Shapiro," Brookings Papers on Economic Activity, Issue 1, pp. 181-225.

(1998). "Foundations of the Goldilocks Economy: Supply Shocks and the Time-Varying NAIRU," Brookings Papers on Economic Activity, pp. 297-333.

Greene, William H. (2002). Econometric Analysis, 5th Edition. (New Jersey: PrenticeHall, Inc.).

Hsiao, Cheng (1986). Analysis of Panel Data, (New York: Cambridge University Press).

Ichniowski, Casey and Kathryn Shaw (1995). "Old Dogs and New Tricks: Determinants of the Adoption of Productivity-Enhancing Work Practices," Brookings Papers on Economic Activity, Microeconomics, pp. 1-55.

Judson, Ruth and Ann Owen (1996). "Estimating Dynamic Panel Data Models: A Practical Guide for Macroeconomists." Federal Reserve Finance and Economics Discussion Paper No.1997-3 (January).

Levin, Andrew and Chien-Fu Lin (1992). "Unit Root Tests in Panel Data: Asymptotic and Finite Sample Properties.” Mimeo, University of California at San Diego.

Mattey, Joe and Stephen Strongin (1995). "Factor Utilization and Margins of Output Adjustment." Federal Reserve Economics and Finance Discussion Paper No. 1995-12 (March).

McElhattan, Rose (1978). "Estimating a Stable-Inflation Capacity-Utilization Rate," Federal Reserve Bank of San Francisco Economic Review, Fall, Vol. 78, pp. 20-30.

Meyer, Laurence H. (1997). "The Economic Outlook and Challenges Facing Monetary Policy." Remarks before the 1998 Global Economic and Investment Outlook Conference, Carnegie Mellon University, Pittsburgh, PA (Sept. 17).

Mohr, Mike and Charles Gilbert (1996). "Capital Stocks for Manufacturing Industries: Methods and Estimates," Federal Reserve Board technical report. 
Nickell, S. (1981). "Biases in Dynamic Models with Fixed Effects," Econometrica, Vol. 49, pp. 1417-1426.

Ramey, Valerie and Matthew Shapiro (2001). "Displaced Capital: A Study of Aerospace Plant Closings" Journal of Political Economy, Vol. 109, No. 5 (October), pp. 958-92.

Shapiro, Matthew D. (1989). “Assessing the Federal Reserve's Measures of Capacity and Utilization," Brookings Papers on Economic Activity, Issue 1, pp. 181-225.

U.S. Census Bureau (1994). "Manufacturing Technology: Prevalence and Plans for Use, 1993.” U.S. Department of Commerce, Current Industrial Reports, SMT 93-3, November.

(2001). "Survey of Plant Capacity Utilization, 1999." Current

Industrial Reports, MQ-C1 (99), March.

U.S. Congress, Office of Technology Assessment (1984). "Computerized Manufacturing Automation: Education and the Workplace." OTA-CIT-235 (April).

Van Biesebroeck, Johannes (2000). "Measuring Productivity Dynamics with Endogenous Choice of Technology and Capacity Utilization: An Application to Automobile Assembly." U.S. Census Bureau, Center for Economic Studies Working Paper CES-WP$00-16$.

Whelan, Karl (2000). "A Guide to the Use of Chain Aggregated NIPA Data," Federal Reserve Finances and Economics Discussion Series No, 2000-35 (June). 
Table 1. Results using High-Tech Share of Investment

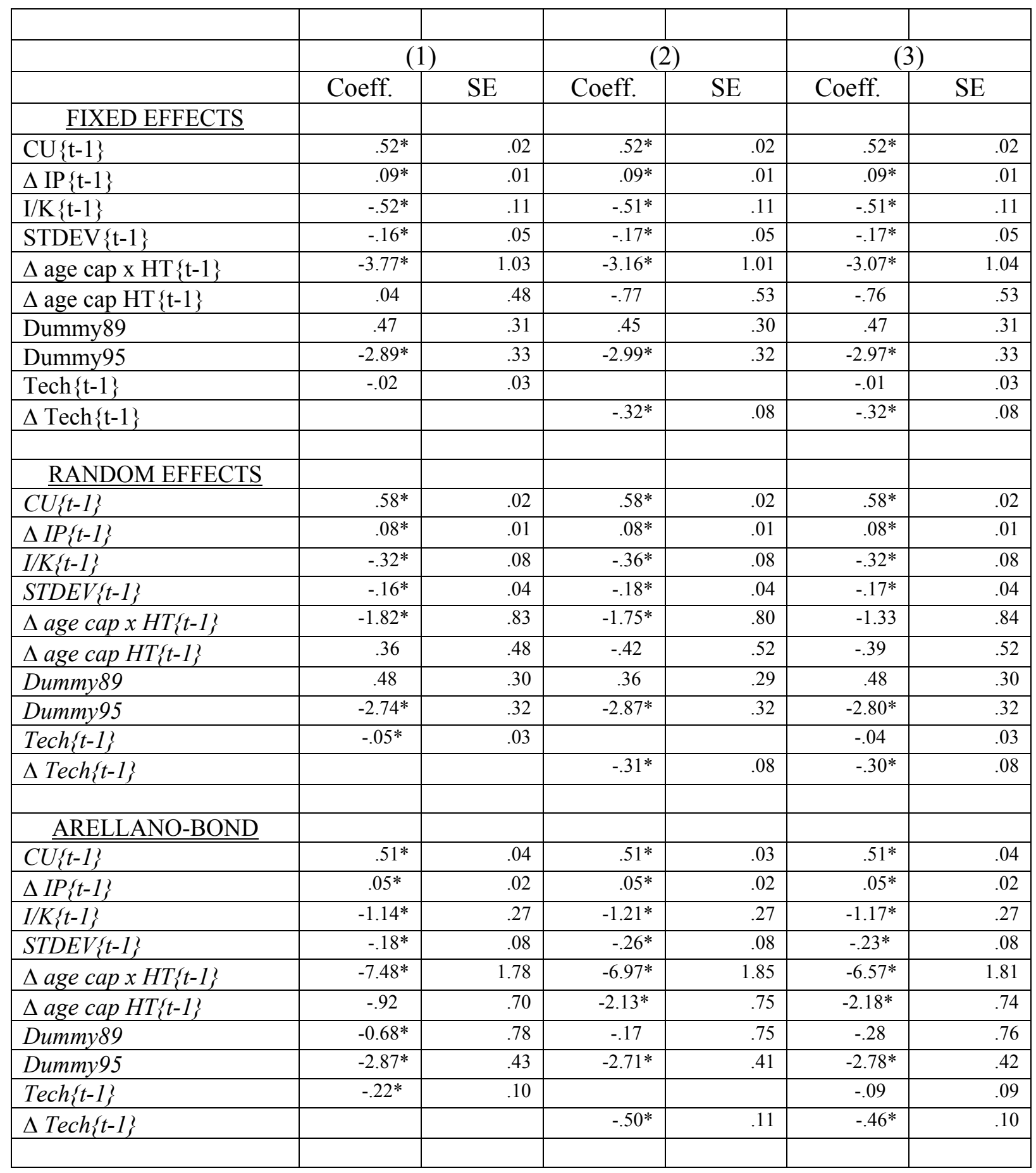

\footnotetext{
$*=$ significant at $5 \%$ level.

$+=$ significant at $10 \%$ level.
}

Notes: All models included constants. Standard errors in the AB models were estimated robustly. 
Table 2. Results using High-Tech Share of Capital

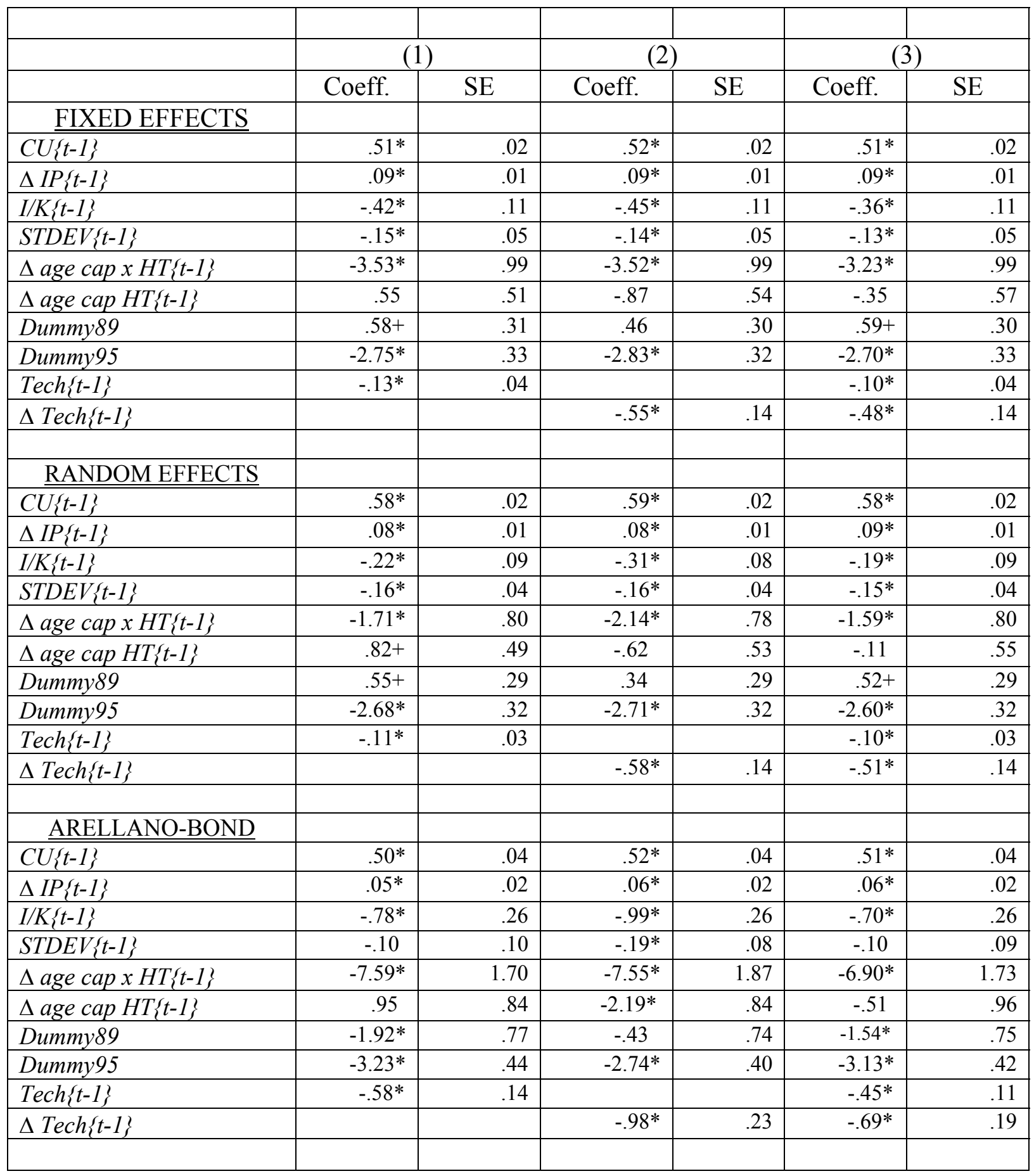

$*=$ significant at $5 \%$ level.

$+=$ significant at $10 \%$ level.

Notes: All models included constants. Standard errors in the AB models were estimated robustly. 


\title{
Table 3. Estimates of effects of technological change on capacity utilization
}

\author{
Estimated effects on capacity utilitization rate
}

\begin{tabular}{|c|c|c|c|c|c|c|}
\hline & \multicolumn{3}{|c|}{ Investment } & \multicolumn{2}{|c|}{ Capital } & \\
\hline & (1) & (2) & (3) & (1) & (2) & (3) \\
\hline Fixed & -0.2 & -0.2 & -0.3 & -1.2 & -0.3 & -1.2 \\
\hline Random & -0.6 & -0.2 & -0.7 & -1.3 & -0.4 & -1.4 \\
\hline Fixed-AB & -2.3 & -0.3 & -1.2 & -5.1 & -0.6 & -4 \\
\hline
\end{tabular}

Note: These are estimated effects of technological change on the capacity utilization rate, based on observed increases in shares of computers in total investment and in total capital respectively, for the average industry, for the 1974-2000 period. (See text for details). 
Figure 1. Capacity utilization and employment rates, 1974-2000

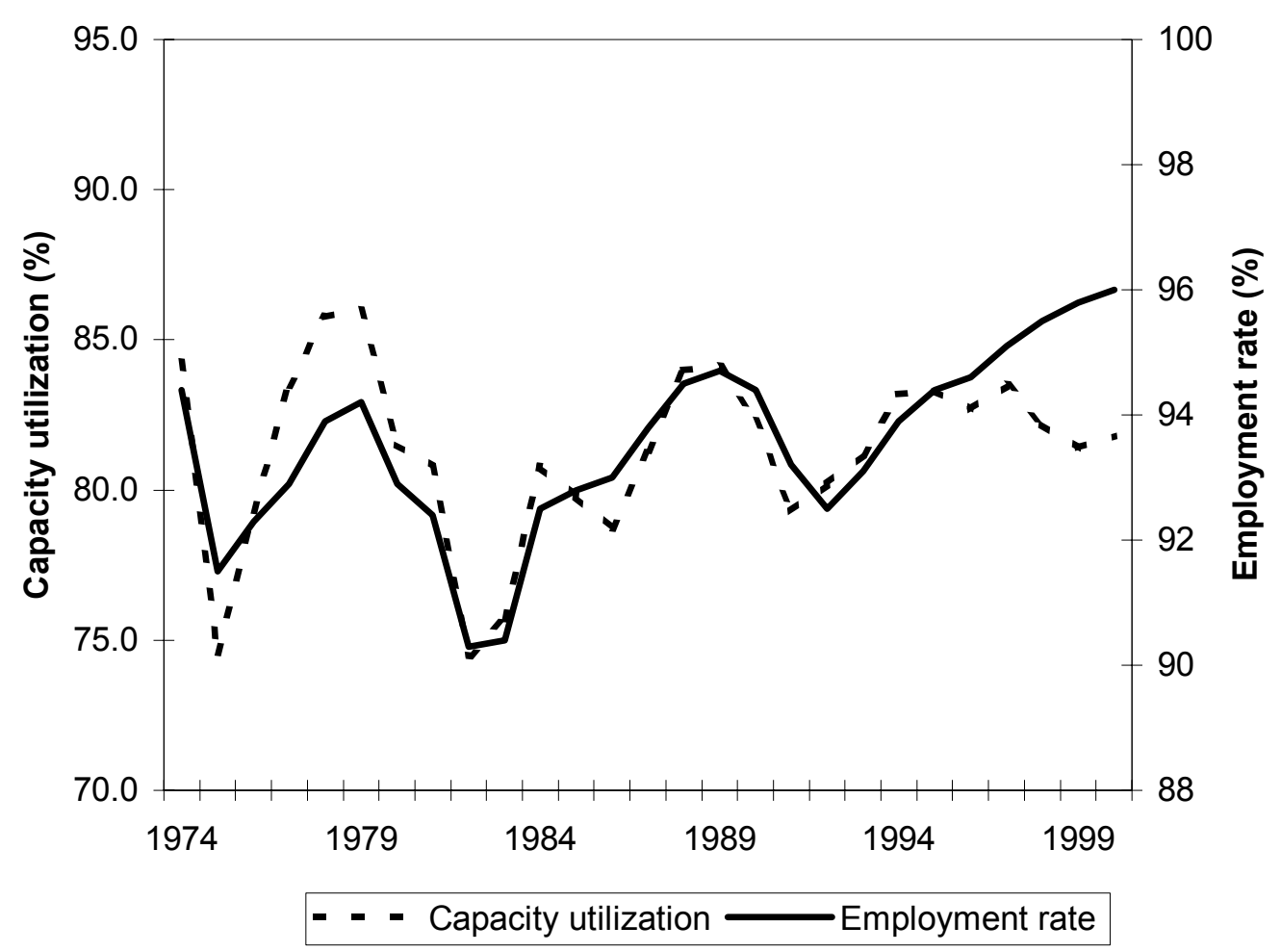


Figure 2. Shares of computers in investment and in total capital, 1974-2000

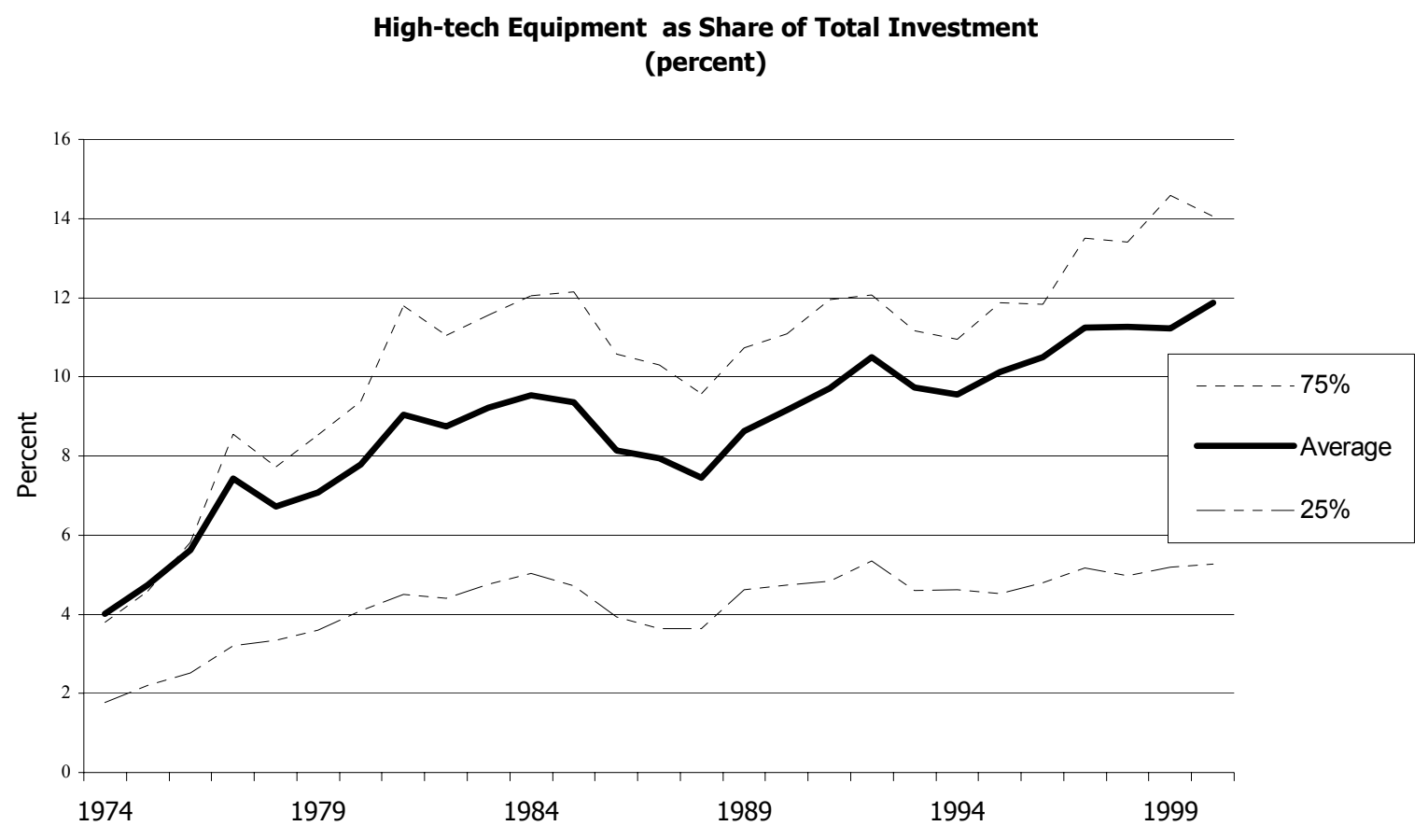

High-tech Equipment as a Share of Total Capital Stock (percent)

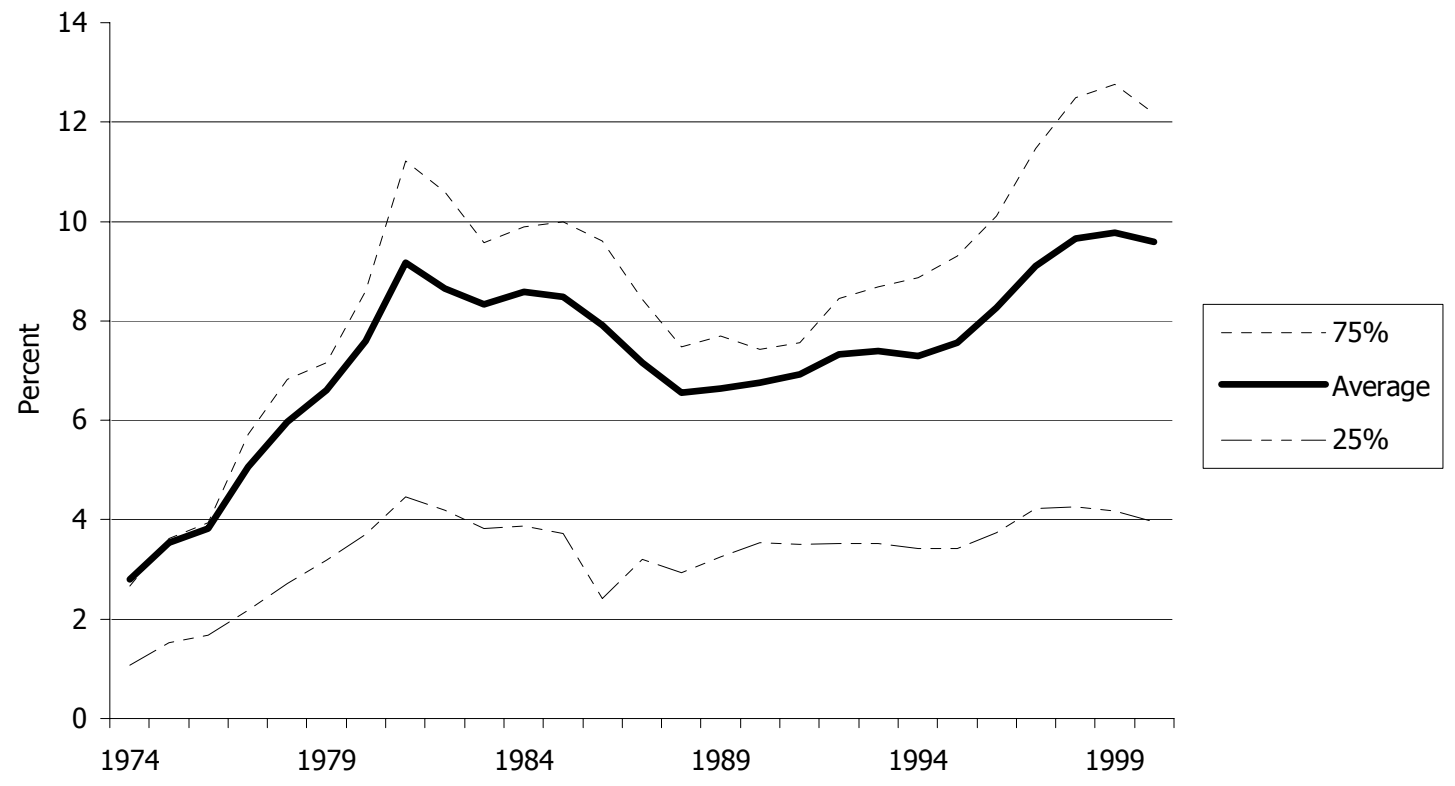




\section{Data appendix}

The empirical analysis was performed using 111 industries, largely at the 3-digit SIC level for manufacturing industries; there are 140 3-digit SIC industries in manufacturing, but we were unable to perform the analysis strictly at the 3-digit SIC level because of the coverage of the lowest-level series in industrial production. Although Industrial Production (IP) statistics completely cover manufacturing, generally at the 3- or 4-digit SIC level, for a few industries, the most detailed individual IP series are combinations of two to five 3-digit SIC industries.

Utilization rates: The Survey of Plant Capacity (SPC) from the Bureau of the Census collects utilization rate data at the 4-digit SIC (from 1974 to 1996) and 6-digit NAICS level (from 1997 on). The SPC utilization rate data on an SIC basis were aggregated to the 3-digit SIC level using value-added weights from the Annual Survey of Manufacturers (ASM) and Census of Manufactures (COM). The SPC data on a 6-digit NAICS basis were converted to the 4-digit SIC level using ASM/COM shipments weights from the Census NAICS-to-SIC bridge tables and the 1997 COM, which was reported both on an SIC and a NAICS basis; the resulting 4-digit SIC data were aggregated to the 3-digit SIC level as above. The two dummy variables in the regressions (from 1989 on and from 1995 on) were included to account for possible effects of changes in the SPC design. Prior to 1989, establishments were asked questions about preferred and practical capacity; from 1989, the respondents were asked about full capacity and national emergency capacity (see Doyle, 2000); the definitions for preferred and full capacities were fairly close, but we included the 1989 on dummy to account for possible differences. Prior to 1995, the SPC form was sent to between 9,000 and 10,000 establishments; from 1995 on, the survey was sent to between 16,000 and 17,000 establishments. A dummy variable from 1995 on was included to account for possible systematic effects on utilization rates from the sample expansion.

Nominal investment: ASM/COM data on capital expenditures on new equipment and structures are compiled at the 4-digit SIC through 1996. From 1997, data were compiled on total capital expenditures on equipment and on structures at the 6-digit NAICS 
industry levels. The data were summed to the appropriate 3-digit level through 1996; bridge tables from the Census, the 1997 COM, and historical averages of the share of investment in new equipment and structures in total investment were used to convert the 1997 to 2000 6-digit NAICS total capital expenditures data to new capital spending on a 4-digit SIC basis.

Real investment: Real investment measures require estimating real industry-by-asset investment and aggregating these data to the industry level with asset-specific price deflators (see Mohr and Gilbert, 1996, for details). This is performed in four steps. First, US-level asset totals are taken from the NIPA data. Second, industry-level investment totals are taken from the ASM/COM; US-level investment less manufacturing is constructed by summing over the NIPA investment categories and subtracting the manufacturing total. Third, given the estimates of total investment by each manufacturing industry (and total US excluding manufacturing) and the total US investment in each asset category, industry-by-asset investment is estimated using the biproportional matrix balancing (or RASing) technique of Bacharach (1965); the initial estimates of the asset distribution of industry investment were taken from the roughly quinquennial Capital Flows Tables (CFT) of the BEA. ${ }^{22}$ The industry-level real investment measures are Fisher chain-weighted aggregates of the asset-level investment flows.

Industry-by-asset capital stocks: Asset-level net capital stocks are constructed using the perpetual inventory model system (PIMS) methodology (see BLS, 1983, and Mohr and Gilbert, 1996). Each asset is assigned a specific age-efficiency profile that describes the proportion of its original efficiency that remains in each period as the asset ages. ${ }^{23}$ For a

\footnotetext{
${ }^{22}$ Given row (asset investment) and column (industry investment) totals that sum to the same value; nonnegativity constraints on investment; and an initial guess on the asset allocation of industry investment, the RASing procedure converges to a unique industry-by-asset investment flow. For the years a CFT exists, it is used as the initial guess for the RASing procedure; for years between CFTs, a linear interpolation of the adjacent CFTs are used; for years after the most recent CFT, the final allocation from the previous year is used as the initial guess for the current year; for years before the first CFT, the final allocation from the following year is used as the initial guess.

${ }^{23}$ The age efficiency profile is based on integrating over all possible asset service lives given a stochastic mean service life and standard deviation (for asset discards) and a hyperbolic beta-decay function (for asset decay). See Mohr and Gilbert (1996) for details.
} 
given industry, the capital stock in a particular asset category is a weighted sum of all past investment flows, where the weights are given by the age-efficiency profile.

Capital stocks: Industry-level net capital stocks are constructed as a Fisher index of the industry-by-asset capital stocks, where the weights are the asset-specific prices (see BLS, 1983).

Current-cost capital stocks: The replacement value, in current dollars, of the net capital stock is constructed by taking the real capital stock levels for each asset category, multiplying them by the asset price deflators for that year, and summing to the industry level.

Capital input: Industry-level capital input measures estimate the potential flow of services derived from the net capital stocks in the various asset categories. They are constructed as a Tornqvist index of the industry-by-asset capital stocks where the weights are the asset-specific rental prices or user costs (see BLS, 1983). The rental price for a particular asset, $p(r+\delta-\dot{p} / p) \tau$, is the marginal product of that asset, where $p$ is the asset price, $r$ is a required rate of return, $\delta$ is a depreciation rate, and $\tau$ is a tax term (see BLS, 1983). As indicated by the formula, an asset that depreciates more quickly will receive a correspondingly higher weight in the aggregation, as will an asset whose price is declining. The computer asset categories, which do both, consequently receive a higher weight in aggregating asset-level capital stocks to an aggregate capital input measure than aggregating asset-level capital stocks to an aggregate capital stock measure.

Age of capital: With the PIMS methodology, the entire vintage history of industry-byasset investment is used. It is a simple matter, then, to construct the average age of capital by weighting each vintage's contribution to a year's current-cost capital stock by the age of that vintage, and dividing the overall sum by the total current cost stock for the industry. 
High-tech share of investment and the high-tech share of capital: The high-tech share of investment is the ratio of current dollar capital spending on computer, office and communication equipment to total current dollar capital spending on all equipment and structures categories. The high-tech share of capital input is the share of capital services derived from the high-tech asset categories; it is calculated by multiplying the asset level capital stocks in the high-tech asset categories by their rental prices and dividing the sum by the sum over all asset categories of the products of the asset level capital stocks and their rental prices. See Whelan (2000) for a lucid explanation of why these sorts of ratios should be formulated in current dollar (for investment) or current cost (for capital) terms. 
Table A1. Variable names and definitions

\begin{tabular}{|c|c|}
\hline Variable name & Definition \\
\hline$C U$ & $\begin{array}{l}\text { CU*100, where CU is the Q4 utilization rate for the 3-digit industry } \\
\text { from the Survey of Plant Capacity }\end{array}$ \\
\hline$\Delta I P$ & $\begin{array}{l}100 \text { times the difference of the log of IP, where IP is industrial } \\
\text { production in Q4 (a physical measure) }\end{array}$ \\
\hline$I / K[t-1]$ & $\begin{array}{l}\text { Nominal investment divided by the current cost lagged capital stock, } \\
\text { times } 100\end{array}$ \\
\hline STDEV & Standard deviation of the log of IP, 10-year moving average \\
\hline$\Delta A G E^{x . h t}$ & $\begin{array}{l}\text { Change in average age of capital equipment, excluding high-tech and } \\
\text { structures. }\end{array}$ \\
\hline$\Delta A G E^{h t}$ & Change in average age of high-tech capital equipment \\
\hline $\begin{array}{l}\text { High-tech } \% \\
\text { inv. }\end{array}$ & $\begin{array}{l}\text { Investment in computer, office and telecommunications equipment } \\
\text { divided by total investment, times } 100, \text { where both are nominal. }\end{array}$ \\
\hline $\begin{array}{l}\Delta \text { high-tech } \% \\
\text { of inv. }\end{array}$ & $\begin{array}{l}\text { The change in high-tech share of high-tech equipment in total } \\
\text { investment, times } 100 \text {. }\end{array}$ \\
\hline $\begin{array}{l}\text { High-tech } \% \\
\text { cap. }\end{array}$ & $\begin{array}{l}\text { Capital stock in computer, office and telecommunications equipment } \\
\text { divided by total capital stock, times } 100 \text {, where high-tech capital stock } \\
\text { is the current- cost rental value of these types of equipment, and the } \\
\text { denominator is the total value of services derived from the capital } \\
\text { stock. }\end{array}$ \\
\hline $\begin{array}{l}\text { Dhigh-tech } \% \\
\text { cap. }\end{array}$ & $\begin{array}{l}\text { The change in share of high-tech equipment in the capital stock, times } \\
100\end{array}$ \\
\hline
\end{tabular}


Table A2. Diagnostic statistics for Arellano-Bond models

\begin{tabular}{|c|c|c|c|c|c|c|}
\hline & \multicolumn{6}{|c|}{ High-tech share of: } \\
\hline & \multicolumn{3}{|c|}{ Investment } & \multicolumn{3}{|c|}{ Capital } \\
\hline & (1) & (2) & (3) & $(1)$ & $(2)$ & $(3)$ \\
\hline \multicolumn{7}{|l|}{ One-step } \\
\hline $\begin{array}{l}\text { Sargan test of } \\
\text { overidentifying } \\
\text { restrictions * }\end{array}$ & $\begin{array}{l}1267.51 \\
\quad(0.0000)\end{array}$ & $\begin{array}{c}1254.68 \\
(0.0000)\end{array}$ & $\begin{array}{l}1257.29 \\
(0.0000)\end{array}$ & $\begin{array}{c}1250.61 \\
(0.0000)\end{array}$ & $\begin{array}{l}1240.35 \\
(0.0000)\end{array}$ & $\begin{array}{l}1237.93 \\
(0.0000)\end{array}$ \\
\hline $\begin{array}{l}\text { First-order } \\
\text { autocorrelation } * *\end{array}$ & $\begin{array}{l}-7.23 \\
(0.0000)\end{array}$ & $\begin{array}{c}-7.19 \\
(0.0000)\end{array}$ & $\begin{array}{l}-7.18 \\
(0.0000)\end{array}$ & $\begin{array}{l}-7.13 \\
(0.0000)\end{array}$ & $\begin{array}{l}-7.18 \\
(0.0000)\end{array}$ & $\begin{array}{l}-7.13 \\
(0.0000)\end{array}$ \\
\hline $\begin{array}{l}\text { Second-order } \\
\text { autocorrelation } * * *\end{array}$ & $\begin{array}{l}-1.07 \\
(0.2855)\end{array}$ & $\begin{array}{c}-1.15 \\
(0.2485)\end{array}$ & $\begin{array}{l}-1.12 \\
(0.2624)\end{array}$ & $\begin{array}{l}-1.14 \\
(0.2549)\end{array}$ & $\begin{array}{l}-0.93 \\
(0.3503)\end{array}$ & $\begin{array}{l}-1.00 \\
(0.3151)\end{array}$ \\
\hline \multicolumn{7}{|l|}{ Two-step } \\
\hline $\begin{array}{l}\text { Sargan test of } \\
\text { overidentifying } \\
\text { restrictions * }\end{array}$ & $\begin{array}{l}106.58 \\
(1.0000)\end{array}$ & $\begin{array}{l}107.28 \\
(1.0000)\end{array}$ & $\begin{array}{l}106.58 \\
(1.0000)\end{array}$ & $\begin{array}{l}105.54 \\
(1.0000)\end{array}$ & $\begin{array}{l}105.86 \\
(1.0000)\end{array}$ & $\begin{array}{l}107.09 \\
(1.0000)\end{array}$ \\
\hline $\begin{array}{l}\text { First-order } \\
\text { autocorrelation } * *\end{array}$ & $\begin{array}{l}-7.05 \\
(0.0000)\end{array}$ & $\begin{array}{c}-7.05 \\
(0.0000)\end{array}$ & $\begin{array}{l}-7.05 \\
(0.0000)\end{array}$ & $\begin{array}{l}-6.94 \\
(0.0000)\end{array}$ & $\begin{array}{l}-6.97 \\
(0.0000)\end{array}$ & $\begin{array}{l}-6.95 \\
(0.0000)\end{array}$ \\
\hline $\begin{array}{l}\text { Second-order } \\
\text { autocorrelation } * * *\end{array}$ & $\begin{array}{l}-1.10 \\
(0.2718)\end{array}$ & $\begin{array}{c}-1.14 \\
(0.2536)\end{array}$ & $\begin{array}{l}-1.10 \\
(0.2718)\end{array}$ & $\begin{array}{l}-1.10 \\
(0.2692)\end{array}$ & $\begin{array}{l}-0.93 \\
(0.3525)\end{array}$ & $\begin{array}{c}-0.96 \\
(0.3363) \\
\end{array}$ \\
\hline
\end{tabular}

* Sargan test statistic is distributed chi-square with 603 degrees of freedom. The number is parentheses is Prob $>$ chi-square.

** Arellano-Bond test that average autocovariance in residuals of order 1 is 0 . The number is parentheses is $\operatorname{Pr}>\mathrm{z}=0.0000$. The one-step estimates come from robust estimation.

*** Arellano-Bond test that average autocovariance in residuals of order 2 is 0 . The number is parentheses is $\operatorname{Pr}>\mathrm{z}=0.0000$. The one-step estimates come from robust estimation. 